\title{
REFLEXÕES EM TORNO DO MAMONISMO
}

José Brendan Macdonald *

A categoria social que chamarei de mamonismo foi objeto de observação pela primeira vez, que eu saiba, em termos de uma sistematização não apenas sapiencial, há 23 séculos por Aristóteles. Ele a chamava de crematística, termo que não permaneceu na história do pensamento, ao que parece em larga medida porque, pelo menos no tocante aos últimos séculos, o mamonismo, embora sem esse rótulo científico nem outro qualquer, é abertamente defendido, o que contraria a disposição contrária a ele por Aristóteles e muitos outros antes da Era Burguesa. Acontece que o mamonismo é o mais forte ingrediente da alma burguesa não obstante as restrições que a opinião pública (não sem ambigüidade) ainda hoje lhe faz.

Mas nós vivemos numa época muito mais privilegiada do que a de Aristóteles para fins de observação da presente matéria. $O$ presente século, prestes a findar, é o mais mamonista de todos. A economia política, a filosofia econômica e outros ramos do saber têm muito a dizer a respeito.

O presente trabalho se divide em sete partes. As cinco primeiras são teses a respeito do conceito de mamonismo em si: a primeira procura definir o conceito, que, por ora diremos, se refere a uma atitude e comportamento que tem o acesso (propriedade) a

"Professor do Departanento de Economia da UFPB - Campus I. Dr, en História pela UFPE. 
bens materiais supérfluos como a manifestação social suprema da realização humana; a segunda dirá que a propensão para o mamonismo é tão antiga quanto a humanidade, e a realização dele, embora näo tão velha, é muito antiga; a terceira atribuirá à discórdia - que ele inevitavelmente provoca - as censuras que a ele surgem; a quarta analisa a relação entre ele e o sagrado; a quinta considera o fenômeno do sacrificio como um valor e conseqüência dele. Na sexta parte veremos a relação entre ele e o fetichismo da mercadoria exposto por Marx; finalmente, na sétima parte, observaremos que, arraigado como está o mamonismo no ser humano em todas as épocas, em graus variados, qual será uma possível implicação disso para o futuro.

\section{$-1-$}

Chamo de mamonismo a atitude e o comportamento humanos pèlos quais a posse permanente de um montante de bens materiais superior àquele possuido por outros sujeitos sociais é tida como o sinal ou símbolo cabal do prestígio humano. Trata-se então de umá ideologia, de uma certa visão de mundo onde está implícita uma hierarquia de valores, ou melhor, uma fração de tal hierarquia, o que no caso dos mamonistas de maior dimensão significa o ápice dessa hierarquia. Mas o mamonismo é conseqüente para o próprio mamonista na medida em que ele passa de atitude a comportamento. Um favelado pode entreter devaneios sobre uma nova condição rockefelleriana sua, pode ser que sonhe com ser e até deseje no seu íntimo ser um rico burguês. Evidentemente ele é um mamonista a nível de intenções tão-só, isto pelo menos no tocante ao ponto máximo (e irrealizável) de seus desejos. Ele será mamonista de pequena dimensão quanto a boa parte do restante de seu comportamento. Comprará talvez roupas e outros bens de consumo mais caros, além do permitido por sua condição ou, quando muito, sentirá viva inveja de quem os tem.

Mamonista então é quem tem aqueles bens socialmente supérfluos como a evidência cabal da sociabilidade humana. ${ }^{1}$ Para ele,

A sociabilidade aqui referida se reporta a convivencia social, seja harmoniosa ou conflituosa. 
ter mais é ser mais. Os mamonistas mais conseqüentes e ambiciosos prezam seu excesso de bens como garantia de respeito por seus semelhantes. Por respeito aqui entenda-se honra ou prestígio e, se possível, uma certa inveja. Como se vê, a prática do mamonismo é uma concorrência pelo supérfluo. $\mathrm{O}$ desejo do indigente de adquirir um padrão minimamente suficiente para garantir a sua integridade física e psíquica em termos de moradia, alimentação, saúde e vestuário não é uma atitude mamonista. Mas o desejo de adquirir mais do que o padrão médio social do grupo do sujeito em questão, desde que se trate de um grupo com um padrão médio por si acima da satisfação das necessidades básicas e de modo que esse desejo reflita um apetite sempre inquieto, é uma atitude mamonista. Porém, não se confunda isto, por exemplo, com a atitude de um jovem universitário hoje, de origem de classe média baixa, que queira ser médico por amor a essa profissão (desejo de realização pessoal pela dedicação aos doentes, fascínio pelo estudo da biologia da química orgânica, etc.) $\mathrm{Na}$ medida em que sua aspiração vocacional seja pura, isto é, não sofra a influência da sedução por um futuro padrão material de vida mais elevado como móvel maior de sua opção, sua motivação não é mamonista. Trata-se de uma distinção não raro dificil na ordem prática mas nem por isso incompreensível na ordem conceitual.

A antítese clara do mamonismo é a atitude e comportamento da rara figura do austero monge ou do asceta. Pouquíssimos da atual sociedade de consumo desconhecem pelo menos uma pequena dimensão de mamonismo.

Para o mamonista de maior dimensão o enriquecimento, o engrandecimento da fortuna, é motivo para que seus semelhantes sintam verdadeira admiração por ele. Para outros o saber pode ser o motivo de respeito, prestígio ou admiração. Ainda para outros é o poder (qualidade social que dificilmente se desvincula do enriquecimento nos últimos séculos). Respeito, prestígio, admiração, eis tudo o que o nosso filho de Mamon espera de seus semelhantes. Quem são estes? São seus pares de fortuna, aqueles que têm

No mesmo sentido, podemos falar na "altura" tanto do anão ou do pigmeu como também na do gigante. 
condições de aspirar a uma fortuna semelhante a dele se ainda não têm. Ou podem em certos casos abranger um universo maior, o resto "pobre" da humanidade nas raras ocasiones em que ele o repara com maior atenção. $O$ mamonista certamente quer ser invejado também: convém.lhe que sempre haja pessoas que não se sintam plenamente realizadas justamente porque ele tem algo que elas não têm. Ele mesmo pode sentir também inveja de outros que têm uma quantidade ou qualidade de bens que ele não tem. $O$ espírito mamonista, quando se apossa o bastante de alguém, não abre mão para trégua o sossego.

Sem dúvida, os critérios do supérfluo são historicamente variáveis, isto é, variam de sociedade para sociedade no tempo e no espaço. Mas não acredito que isso em si dificulte a compreensão do conceito de mamonismo.

\section{$-2-$}

Se assim conviermos o presente conceito, ninguém negará que se trata de uma ideologia e uma prática típicas da nossa sociedade de consumo de fins de milênio, de que pouquíssimas pessoas estão totalmente isentas. Seria um fenômeno, se não limitado a ela, pelo menos aos últimos séculos ou à Era Burguesa, a do mercado mundial. Todavia, quero demonstrar que, pelo contrário, a propensão para o mamonismo é universal, isto é, se encontra presente em todas as sociedades humanas do presente e do passado, muito embora em graus variados. E a realizaçāo dele se encontra presente, também em graus variados, desde os albores da própria civilização (sociedades com Estado, cidades, escrita, divisão social do trabalho, camadas sociais, etc.).

Mesmo no seu nível mais primitivo a sociedade humana não desconhece evidências de uma propensão universal para o mamonismo. Refiro-me à sociedade paleolítica, aquela dos povos de caçadores, pescadores e coletores, não praticantes portanto, por desconhecimento ou outros motivos, da agricultura. A este nível do desenvolvimento das forças produtivas, é evidentemente impossível alguém se imaginar um Rockefeller, um Fugger, um Midas, ou 
sequer dono de um próspero rebanho de gado, pois o que os olhos não vêem o coração não sente.

Entre os Kung, povo de caçadores e coletores do Deserto do Kalahari da África austral, a troca de presentes (inclusive no seio de cada pequeno bando) é muito freqüente. A quase totalidade mo modesto montante dos poucos e parcos bens de uso pessoal e boa parte dos instrumentos de trabalho de qualquer integrante de um bando desta etnia já pertenceram a outros integrantes e se destinarão futuramente como presentes a terceiros. Conversas sobre trocas de presentes são freqüentes entre eles. Como nota uma antropóloga que viveu entre eles: "Para os Kung é fácil, com suas capacidades de observação e memória visual altamente desenvolv:das, levarem em conta os objetos mais comuns, saberem quem são seus donos e conhecerem a história de cada troca de presentes"." Note-se porém: "Ninguém depende da aquisição de objetos através da troca de presentes", pois os adultos Kung de ambos os sexos são capazes de fazer absolutamente tudo de que precisam, e habitam um meio ambiente o suficientemente generoso para a satisfação de suas necessidades materiais segundo, claro, seus pxóprios padrôes. ${ }^{3}$

O que motiva a constante troca de presentes entre os Kung é o intento de contornar tensões, invejas e ciúmes e de corroborar amizades e estima. Além do mais, os Kung não comerciam entre si, isto é, desconhecem o escambo, pois acham que é indigno, deselegante e uma possível fonte de mágoas. Ele é reservado apenas para com seus vizinhos bantus. ${ }^{4} \mathrm{O}$ sentido da propriedade privada é extremamente tênue entre eles. A atitude deles sobre o comércio (a troca calculada de bens úteis) e a troca de presentes são reflexos de uma ideologia de nivelamento econômico, de uma ideologia antimamonista. Tudo isso indica que eles percebem a possibilidade do surgimento de um mamonismo, que percebem uma propen-

\footnotetext{
${ }^{2}$ Lorna Marshall, "Sharing, talking, and giving: relief of social tensions among the Kung" \{1961\} em Richard B. Lee e Irven De Vore, organizadores, Kalahari huntergatheres, p.366, Harvard University Press, Cambridge Massachusetts e Londres, terceira impressão, 1982.

${ }^{3}$ Idem, p.367.

${ }^{4}$ Idem, p.365.
} 
são sua para o mamonismo.

Poderíamos fazer semelhantes citações de não poucas monografias que a literatura antropológica ao longo deste século tem dado à luz. Mas para o presente finalidade que baste dizer que tais observaçōes poderiam ser feitas sobre todos os povos primitivos, tanto na etapa paleolítica (pré-agrícola) como na neolítica (agrícola - o que não descarta a coexistência da pesca e caça com uma u outra forma de lavoura e não raro pecuária também). $\mathrm{Na}$ sociedade paleolítica o consumo de um montante de bens notoriamente maior por uns em relaçãc a outros seria pouco concebível num ambiente onde não existe, a não ser esporadicamente, um excedente econômico. Tal comportamento acarretaria a fome aos prejudicados e seria uma ameaça à sobrevivência física até mesmo do próprio grupo como um todo. Mesmo na sociedade neolítica, onde já existe um excedente, embora muito mais modesto do que aquele que aparece nas sociedades posteriores, a possibilidade da apropriação indébita de maior montante de bens por uns poucos às custas de outros é percebida como o fatídico ponto de partida de uma sociedade de ricos e pobres. Daí o surgimento de mecanismos da sociedade neolítica para minimizar o uso desigual do seu excedente. Como o reloteamento periódico das terras entre as famílias da aldeia, a redistribuição consensual do excedente mais generoso produzido por famílias de terrenos mais férteis e a prática da abreviaçăo da jornada de trabalho da parte de famílias que têm um número de braços notavelmente acima da média das famílias da comunidade. 5

Em suma, embora o mamonismo não consiga tomas corpo na sociedade primitiva, o seu possível surgimento é percebido pelo homem da Idade da Pedra. Tal surgimento é tido como fonte de riqueza e poder para uns e de pobreza e fraqueza para outros, é

5 Por motivos que não posso expor aqui, vejo o excedente como um conceito válido apenas quando aplicado a comunidades humanas, e năo a individuos isoladamente considerados. Sobre isto e sobre os mecanismos usados pela sociedade neolítica para contornar a distribuiçáa desigual do excedente entre seus membros ver José Brendan Macdonald, "A questão do excedente na sociedade primitiva", Revista de Cultura Vozes, p.30-46, ano 80 , $\mathrm{n}^{\circ}$. 8, outubro de 1986 , Petrópolis, RJ. 
daí mal visto e ideológica e praticamente inibido. ${ }^{6}$ A sociedade primitiva - a única sociedade sem classes (ou sem ordens, castas, estamentos ou qualquer tipo de camada social) até hoje - é a sociedade antimamonista por excelência.$$
-3-
$$

Podemos falar em mamonismo triunfante somente a partir da civilização. Se por progresso entendemos o crescente domínio do homem sobre a natureza, então é com a civilização que ele começa, aliado como ele é da ciência. Na Idade da Pedra os avanços no sentido foram mínimos, tanto que parece mais plausível falarmos nele só a partir da civilização. É até razoável especular que a origem da civilização - com a sua diferenciação entre mandantes e mandados, ou seja, entre, por um lado, planejadores e, portanto, os que têm menor acesso - nem sempre se encontre numa imposição pela força senão, em muitos casos, num relativo consentimento popular com a expectativa de se receber em troca um mais eficiente cultivo do progresso por uns poucos especialistas.

A abundância de bens que só a civilização tem podido garantir enseja um certo triunfo do mamonismo. Mas desde os primórdios da civilização, se há quem se fascina com a concorrência pelo supérfluo, há também quem desconfia dela ou até a condena. Mamonistas foram boa parte dos príncipes e de seus séquitos, ansiosos por tributos extraídos de seus pobres súditos e ainda motivados para a guerra não só pela glória militar mas também pela fome de botim e até de novos contribuintes. Sem isso o esplendor e a pompa do luxo principesco teria sido impossível. Impossível sabermos qual o seu peso entre as antigas aristocracias. Basta sabermos que eram muitos os aristocratas mamonistas de então, não obstante a veja antimamonista presente nas oficiais doutrinas re-

\footnotetext{
${ }^{6}$ A sociedade primitiva também percebeu a possibilidade do surgimento de um Estado antes que este existisse, o por motivos ideológicos que não cabe discutir aqui, tomou medidas contra ela. Ver a respeito o muito sugestivo livro de Pierre Clastres, $A$ sociedade contra o Estado, pesquisas de antropologia politica $\{1974\}$, Livraria Francisco Alves Editora, Rio de Janeiro, 1978.
} 
ligiosas mundo civilizado afora. Mamonistas de espírito havia no seio das populações também. A figura do pobre, que se alegra ao ver a pompa e o luxo de seus auperiores na escala social, tão comum no mundo ainda nestes fins de milênio, é certamente tão antiga quanto a própria civilização. ${ }^{7} \mathrm{E}$ os mamonistas mais conseqüentes de todos, antes da Era Burguesa, foram os grandes comerciantes e, acima de tudo, os grandes agiotas ou prestamistas, estes os precursores dos modernos banqueiros.

Os adversários do mamonismo são, como já dissemos, tão antigos como a própria humanidade. Mas se o mamonismo chega a ser conseqüente somente a partir da civilização, é só então também que a oposição a ele se acentua. Disso não faltam indícios milenares em países tão diversos como a China, a Índia, o Egito e outros. Aristóteles condenava a crematística chrematisitke), ou arte de adquirir bens pela aquisição em si, que ele opunha à economia (oikonomia), a legítima arte de organizar e zelar pelo uso dos bens pela família no seu lar (oikos). Ele condenava, daquela decorrente, a usura ou cobrança de juros, como antinatural, ${ }^{8}$ como também

${ }^{7}$ Elucidativa a este respeito é a versão biblica dos antecedentes da institucionalização da monarquia em Israel por exigência popular, tal como relatada no capítulo 8 do Primeiro Livro de Samuel, onde os israelitas, malgrado vigorosas advertências divinas sobre os inconvenientes da nova instituição, especialmente do ônus dos pesados tributos aos reis futuros, insistem em optar por ela. Todo esse suor e sacrificio em troca de um espetáculo de esplendor, pompa e vaidade. Trata-se de uma historia atual, pois o pobre hoje ainda internaliza o pensamento burguês sobre a riqueza.

${ }^{8}$ A respeito de tudo isso ver Aristóteles, A política, Livro 1, 1256al a 1258a38. Vale a pena lembrar que Chremata em grego significa bens ou dinheiro e que chrematismos é negócio. Chrematistike, palavra já existente na época e não criação de Aristóteles, tinha o significado de "a arte de lucrar, trocar bens, ganhar dinheiro". Neste sentido, ela não tem necessariamente o mesmo significado de mamonismo. Mas o modo de que Aristóteles a usa, ou seja, sua atitude para com esta "arte" faz com que seja o vocábulo de sentido mais próximo possivel do nosso mamonismo, senão idêntico a ele.

Segue dessa obra um trecho onde ele evidencia uma abordagem psicológica ao fenômeno. É um bom exemplo também do selu espirito antiburguês, em certo sentido:

A causa dessa disposiça de espirito, que se pensa ra vida e não na boa vida; e, sendo esse desejo ilimitado, procura-se mulliplicar ao infinito os meios de o realizar. Há outros que, aspirando à boa vida, procuram também os prazeres do corpo, e parecendo que esses prazeres se firmam na aquisição de propriedade, outra coisa não fazem que dedicar-se aos negócios. $E$ ai está como surgiu este outro ramo da ciência das riquezas fa cremallstica, 
Maomé, séculos depois, a condena como pecaminosa. Assim, o agiota, a personificação máxima do mamonismo das civilizações préburguesas, foi o grande alvo de notórias críticas de muitos homens pensantes - e das massas. Os profetas de Israel cultivaram uma lábia violenta contra a ideologia e a práxis mamonistas. Jesus, e discípulos seus como Paulo de Tarso e Tiago, deram continuidade ao discurso antimamonista. Buda recomendou a todos os seus discípulos o desapego à riqueza e à propriedade.

Antimamonista também foi e é o homem comum de todas as sociedades civilizadas. $\mathrm{Em}$ muitos casos se trata de um antimamonismo radical, mas em muitos outros, talvez mais freqüentes, se trata de um antimamonismo entretido pelo mesmo homem comum que em outros momentos é profunda e fantasiosamente seduzido pelo mamonismo deslumbrante de seu príncipe ou de seu patrão milionário.

O progresso que a civilização trouxe nunca beneficiou a todos, senão a determinadas parcelas da sociedade. É uma lei (padrão, tendência universal) o progresso se propagar assimetricamente. Na sociedade civilizada - na de ricos e pobres - o maior domínio sobre a natureza é administrado pelos ricos e poderosos e, via de regra, eles preferem beneficiar as suas camadas sempre, ao passo que beneficiam as inferiores apenas em determinadas circunstâncias - quando estas surgem. Na civilização burguesa isso funciona não raro até automaticamente: as lei do mercado cuidam da distribuição, pois os benefícios do progresso aparecem quase sempre em forma de mercadoria, o que por si significa o consumo do progxesso apenas de acordo com o poder aquisitivo.

O mamonismo pode trazer como efeito notável o progresso des-

contraposta à economial. Sendo extremamente variados os prazeres mundanos, procuram eles o meio de alcançar a abastança, que faculta os prazeres. E quando não podem obtê-los por melo dos negócios, tratam de obtê-los por outros meios, fazendo de todas suas faculdades um uso em desacordo com a natureza. Por exemplo, a coragem não se destina a proporcionar-nos os bens, porém deve dar-nos uma generosa audácia. A produçâo de bens não é o objeto da ciência militar nem o da medicina; são a vitória e a saúde. E no entanto faz-se de todas as profissóes um caso de dinheiro, como se tal fosse o fim delas e iudo a ele devesse concorrer. $(1257 b 40)$. 
ta maneira historicamente recorrente. $O$ príncipe de aguçado espírito mamonista extraía impiedosamente tributos de seus súditos camponeses que se estafavam de sol a sol para que ele vivesse no luxo mais requintado que a época permitia, ou os arregimentava na entressafra para que, debaixo da chibata, construíssem pirâmides e outros colossais monumentos em homenagem a ele e sua linhagem. No século XIX os capitães de indústria dos países centrais e no século XX mormente os dos países periféricos têm extorquido jornadas maiores de 12 horas em troca de salários de fome para construir um progresso espetacular mas assimétrico. Na Era Burguesa, como nunca antes, graças ao alto desenvolvimento das forças produtivas combinado com o predomínio de relações de produção ditadas por uma nova classe, primeiro ascendente e depois dominante, que é a burguesia - calculista de custos e oportunidades de mercado, avaliadora do trabalhador como mais um "fator de produção" e impelida, queira ou não, pelas exigências da infatigável concorrência capitalista -, esta mesma nova classe presta homenagem a Mamon e impõe a sua ideologia e a sua lei. $O$ seu móvel é o lucro. Tanto os apologistas como os adversários do sistema burguês estão de acordo com isto. Muito mais do que o clássico senhor do mundo outrora, o valente príncipe ávido de glória militar, o burguês almeja o lucro, até sofregamente. Aquele tinha que render homenagem à religião - cristã, islâmica, hindu ou outra - que tinha fortes elementos antimamonistas. (Até onde ele valorizava isso pessoalmente é outra questão. $O$ importante a frisar é que a sua época lhe impunha uma forte pressão ideológica). Os ídolos deste (do burguês) - não obstante o discurso paternalista ou até mesmo um tanto antimamonista que tem que pronunciar em certas ocasióes para o público externo - são a filosofia de mestres como Maquiavel, Locke, Smith, etc., para quem as boas intenções não se casam com a felicidade geral.

A oposição ao mamonismo em qualquer época e qualquer sociedade deve-se basicamente ao fato de que ele é fonte de discórdia. Na Idade da Pedra Lascada (antes da descoberta da agricultura) o seu triunfo teria desembocado na extinção física geral. $\mathrm{Na}$ época neolítica a tolerância dele provocaria a divisão entre pobres e ricos, isto é, o surgimento da estratificação social. Sabemos que é 
efetivamente isto o que ocorreu após milênios de resistência, pois surgiu a civilização. Com ela se vê pela primeira vez que uma minoria vive com a cornucópia ao passo que a maioria vive com uma relativa carência material que varia entre uma tenuidade bastante confortável e um estado de privação infernal. É perceptível também - muito embora poucos cheguem a decifrar tão desagradável verdade - que há uma relação causal que permeia a dicotomia riqueza/pobreza: a riqueza dos poucos é a causa da pobreza dos muitos, são as duas faces da mesma moeda. Mas esta exploração, percebida como tal ou não, ${ }^{9}$ é tolerada justamente porque se espera que através dela e em troca dela o rico devolva ao pobre a sua proteção e outros benefícios e ainda o glorioso espetáculo de sua pompa.

O mamonismo também é fonte de discórdia entre seus próprios adeptos. Às vésperas do terceiro milênio, quando o mamonismo é simultaneamente causa e efeito de um padrão de vida e de uma cultura do cotidiano antes inauditos, o homem comum se apega a ele como nunca antes, pois agora ele faz parte dos $15 \%$ da humanidade que se enquadram de fato neste padrão consumista, e quando não faz parte dele, ele nutre a esperança de alcança-lo um dia ou, mais realista, apenas se permite alguns devaneios a respeito, o que os meios de comunicação, as loterias, etc. não deixam de lhe ocasionar constantemente. Entre os $15 \%$ que têm, a corrida interminável atrás do supérfluo que o consumismo lhes propõe (se é que não se deve dizer que lhes impõe) lhes proporciona uma insatisfação e vazio emocional, pois a lógica do consumismo (forçosamente orquestrada para não ter fim e ela é incapaz de satisfazer algo que ultrapasse as exigências do material, do visual.

${ }^{9}$ A consciência da exploração do homem pelo homem, ou, exatamente, do pobre pelo rico, foi a causa de inúmeras revoltas camponesas ao longo da história universal. Em 1381, por exemplo, durante um levante em que camponeses ingleses, inspirados na doutrina teológica de Wycliffe e convictos da igualdade entre os homens dos primórdios da sociedade humana, entoavam os versos: "Quando Adão cavava e Eva tecia/ onde estava o nobre?" Impressionante é que os camponeses alemães de inspiração anabatista no século XVI, talvez por influência da propagação de idéias Wycliffianas na Boêmia por Huss mais de um século antes, entoaram os mesmos versos nas suas batalhas contra a nobreza. Ver André Maurois, Histoire d'Angleterre, p.246, Artheme Fayard et Cie, Paris, 1937 e Cornelius Castoriadis, A insituição imaginária da sociedade $\{1975\}$, p. 187, Paz e Terra, Rio de Janeiro, terceira edição, 1991. 
Entre os que não têm, o espírito mamonista ao contagiá-los, tampouco desconhece frustrações e desesperanças. Pois almejar ter mais para ser mais quando isto é impossível jamais poderá oferecer consolo.

A discórdia que ocorre entre os filhos de Mamon mais ilustres, os megacapitalistas dos últimos tempos, é maior ainda. Como sentencia o economista Franz Hinkelammert: o empresário vale só quanto e enquanto tem. No século passado ele empregava métodos até sanguinários e de pirataria contra seus concorrentes. Estes, sendo do mesmo porte dele hoje em pleno capitalismo monopolista (era dos oligopólios transnacionais) não são mais enfrentados assim, mas nem por isso a discórdia desaparece. Ela apenas inventa um modus vivendi, e a tensão da infindável concorrência permanece.

Em suma, onde quer que conheça um triunfo maior ou menor, o mamonismo gera discórdia. Discórdia entre os que não têm, pois sentem-se fraudados (conscientemente ou não) pela crueldade dos ricos e poderosos que impiedosamente lhes extraem um excedente sem descanso ou, em certos casos, porque sonham com ter aquilo que jamais poderão ter. Discórdia entre os que não têm, pois, por mais que tenham, sempre querem ter mais ainda, já que nunca lhes faltará à imaginação o próximo que terá algo que eles ainda não têm mas que deveriam ter. Pois o ter mais e sempre mais é a garantia do status a que eles julgam soberbamente ter jus. ${ }^{10}$

$$
-4-
$$

O mamonismo sempre tem como referência o sagrado. $O$ bomem tem como sagrado aquilo que julga como além da sua com-

\footnotetext{
${ }^{10}$ A este respeito escreveu Paulo de Tarso há quase dois milênios atrás: "Porém os que querem ficar ricos caem na tentação e na armadilha de muitos desejos tolos e maus, que levam o homem para a desgraça e a destruição. Porque o amor ao dinheiro é fonte de todos os tipos de males. E alguns, por quererem tanto o dinheiro, (...) encheram sua vida de sofrimentos". Da Primeira carta a Timóteo, capítulo 6, versículos 9-10.

"O amor ao dinheiro é fonte de todos os tipos de males" já era provérbio internacional da época, o que significa que também fazia parte de outras tradições além da judaico-cristâ.
} 
preensão, bom e inquestionável. O sagrado é tido como o sobrenatural, isto é, aquilo que está além da natureza tal qual captada pelo intelecto humano, aquilo que não é possível compreender plena ou satisfatoriamente. O sagrado é bom, opera em favor da verdade e do bem, mesmo que o sujeitos humanos nem sempre consigam entender-lhe os desígnios. Daí ele exige a fé dos homens. Trata-se de algo além de todo questionamento.

$\mathrm{O}$ conceito de sagrado é tradicionalmente associado ao de religião, por sua vez tão associado ao de encantamento do mundo. Mas mesmo que se aceite a (dúbia) premissa de que a religião neste sentido restrito está em declínio irreversível hoje, num sentido menos tradicional do termo, ela está viva, tão viva como sempre foi. Marx fala na "religião da vida cotidiana" ou na "religião econômica" cultivada pelo businessman moderno. Este tem uma fé no dinheiro, no capital, no lucro e nas leis do mercado não menos vacilantes que a dos mártires cristãos que enfrentavam as garras dos leões nos anfiteatros do império romano." Além do mais, a onipresença das instituições do atual sistema econômico - a mercantilização e monetarização de um número cada vez maior de transações humanas, a bolsa de valores, o cartão de crédito, os bombardeios diuturnos de todo tipo de propaganda comercial a respeito de tudo desde o feijão até o sexo pelo telefone, o talão de cheques, etc. - faz com que a vida do homem comum, permeada por elas, as respeite e até as valorize como fatos corriqueiros e imprescindíveis da vida.

Se a práxis econômica burguesa é mais uma religião, convém notas que ela tem também todo um discurso teológico seu. Afinal, toda religião exige uma teologia ou sistematização dos conhecimentos sobre o seu deus ou deuses. A este respeito, Hugo Assmann se refere ao "desvendamento de uma, implícita ou explícita, 'fala de Deus' (god-talk) na economia. Teologia é isso: a refle-

11 "A existência monetária das mercadorias em papel é de natureza apenas social. É a fé que salva. A fé no valor monetário - o espirito imanente das mercadorias -, a fé no modo de produção e tra sua ordem predestinada, a fé nos agentes privados da produção, meras personificações do capital que se valoriza". Karl Marx, O capital \{1894\}, Livro III, p. 679, Civilização Brasileira, Rio de Janeiro, 1968. 
xão, em níveis diversificados de elaboração, sobre os deuses (e os demônios) nos quais os homens, de uma ou outra forma, acreditam e com os quais presumem ter diferentes graus de contato na história". " Como toda teologia, a da religião econômica tem seus dogmas e até mistérios. Um dos mais evidentes deles, e mais celebrados até hoje, é o da famosa mão invisível de Adam Smith. Escrevendo com uma euforia risonha, diz Smith:

Preferindo 0 apoio da indústria nacional à estrangeira, ele fo investidor $\}$ visa só a sua própria segurança. Direcionando essa indústria de uma maneira tal que seu produto tenha o maior valor possível, ele visa somente ao seu próprio ganho, e neste caso, como em tantos outros, ele é conduzido por uma mão invisível a promover um fim que não fazia parte absolutamente de seu intento. E nem sempre a sociedade tira prejuizo disso. Perseguindo seu próprio interesse, ele não raro promove o da sociedade mais eficazmente do que quando realmente pretende promovê-lo. Eu jamais soube de grande bem proveniente daqueles que se meteram no comércio pelo bem público. De fato se trata de uma afetação, não muito comum entre os comerciantes, e pouquíssimas palavras precisariam ter empregadas para dissuadi-los de tal intento. ${ }^{13}$

Não obstante o secular apego liberal (e agora "neoliberal") a sste suposto equilíbrio automático e natural do mercado, o século XX conhece maciças intervenções dos governos na economia. Apesar da intransigente retórica nesse sentido que diz que é preciso sempre uma mais livre atuação do mercado - livre da intervenção do Estado -, os governos gastam trilhões de dólares com seus orçamentos, não só para gastos sociais (em última instância para contornar descontentamento social, pois estes gastos existem unicamente em razão da pressão popular) mas também para comprar armas, manter sua máquina burocrática e até dar subsídios a empresários. Sem isso o edifício social e econômico desmoronaria. $O$

${ }^{12}$ Hugo Assmann e Franz Hinkelammert, A Jdolatria do mercado, p. 10-11, Ediçסes Paulinas, São Paulo, 1989. O "enredo" deste grande ensaio é de Assmann. Os escritos de Hinkelammert inseridos no livro, embora bastante pertinentes, são complementares.

${ }^{13}$ Adam Smith, An inquiry into the nature and causes of the weallh of nations $\{1776\}, \mathbf{p}$. 477.478, University of Chicago Press, Chicago, 1976. 
dogma da mão invisível, do equilíbrio espontâneo da demanda e da oferta, é um mistério. O mercado de fato pode funcionar livre ou espontaneamente, mas a médio, ou mesmo a curto, prazo isto não acarreta o equilíbrio, quanto mais num sistema onde a crise é a regra, não a exceção. Mas nem por isso deixa de fazer parte do credo da religião econômica da maior parte da burguesia, inclusive com uma ressurgente euforia nos últimos anos. E tudo isso com as roupagens de uma certa cientificidade.

Outro conceito teológico da religião econômica (que tem muito a ver com o mistério da mão invisível) é o da racionalidade. Para Max Weber a racionalidade se refere a comportamentos que visam na atividade econômica a determinado fím ou plano. ${ }^{14}$ Mas, especificamente na sociedade burguesa, onde o mamonismo tende a penetrar de forma crescente e interminável a vida social, racional é toda atividade que vise a acumulação de capital. Não há outro comportamento que se deve priorizar. Só a acumulação construirá a felicidade dos aptos. ${ }^{15}$ Mas como, através de quem? A este respeito diz Hugo Assmann:

"A 'racionalidade econômica' reside basicamente nos indivíduos. É fundamental reter este aspecto, porque se liga diretamente ao conceito de 'liberdade econômica' e propriedade privada. É no âmbito da 'racionalidade' subjetiva que ela é santificada. Mas essa 'racionalidade' não deve ser confundida, sem mais, com consciência. Pode até ser considerada na linha do 'servo arbítrio' (de Lutero). Servo de que? É aí que se dá um salto de uma teologização a outra. A 'racionalidade' é atribuida também a algo que está fora dos indivíduos: o mecanismo da competitividade. A 'racionalidade econômica' é esse conjunto: a 'racionalidade' subjetiva dos indivíduos (proprietários) governada pelos 'imperativos da racionalidade econômica', que derivam do mecanismo (divinizado) da concorrência.

${ }^{14}$ Max Weber, Economia y sociedad $\{1922\}$, p. 46. Fondo de Cultura Económica, México, primeira reimpressão, 1969.

${ }^{15}$ Segundo Francis Fukuyama, tudo isso deve desembocar em consumismo, fruto da magia do mercado e dos "milagres econômicos" (outra metáfora mágico-religiosa), um dos maiores beneficios da sociedade atual. Ver o seu The end of history and the last man, Macmillan, Inc, Nova York, 1992. Há uma edição brasileira também. 
Como se pode ver, unn constructo teológico fantástico." "\#6

Como toda religião, a religião econômica exige sacrifícios. Mesmo antes da Era Burguesa, quando a religião econômica, ainda embrionária ou subdesenvolvida, era a confissão apenas dos grandes agiotas e prestamistas e outros ímpios refratários frente ao evangelho - cristão, hindu ou outro - da fraternidade humana, e portanto desprezada pela ideologia oficial e pela opinião pública, ela, com seus poucos adeptos, exigia audazmente sacrificios. Em contraste com a antiga filosofia que exaltava o valor de uso dos bens, a religião econômica, quanto mais quando nos últimos séculos ela rompe as amarras do antigo humanismo, anuncia o sacrificio do homem comum, ou näo-proprietário, "em altares de uma exterior compulsão total". ${ }^{17}$

$\mathrm{Na}$ religião o sacrificio é feito como uma troca de favores com o céu. O homem religioso oferece sacrificios como um gesto de gratidão ou louvor por beneficios conseguidos, ou então - e aqui surge o que se revela às vezes como o lado instrumental, interesseiro ou mesquinho da religião - como antecipação de favores a alcançar. Exemplo do primeiro tipo de sacrifício é o voto feito em uma missa como reconhecimento de "uma graça alcançada". O segundo tipo pode ser exemplificado pela promessa de se construir um templo assim que se consume uma vitória militar ou que se arrefeça uma tempestade ameaçadora.

O progresso que a humanidade conhece a partir da acumulação de capital iniciada no século XV exige constantemente sacrificios do segundo tipo. Nos albores dessa acumulação as novas potências marítimas do Atlântico Norte lançaram um assalto mamonista, nunca antes visto nos anais da histórica universal, aos

\footnotetext{
${ }^{16}$ H. Assmann, op. cit, p. 151. A ênfase é de Assmann.

${ }^{17}$ Karl Marx, Formaciones económicas precapitalistas \{1939\}, p. 136, Editorial Ayuso, Madri, 1975.
} 
povos europeus do mundo. $O$ tráfico negreiro ceifou milhões de vidas prematuramente nas plantations e minas das Américas e pela encomienda os conquistadores espanhóis extraíram a ferro e fogo pesados tributos a milhões de ameríndios. Havia na mesma época também a exploração do próprio homem branco pelo homem branco: milhões de camponeses na Europa foram expulsos de suas propriedades e posses ante a devastação infligida por aventureiros, esses novos discípulos de Mamon, apoiados passiva e ativamente pelas autoridades constituídas, ávidos de novas terras aonde impor a pecuária, a silvicultura e outras atividades provocadas pelo nascente e promissor mercado mundial. Depois veio a Revolução Industrial a chupar o sangue e o suor de legiões de homens, mulheres e crianças com estafantes jornadas e salários de fome. Este processo está longe de terminado, pois, mesmo reconhecendo o arrancamento de concessões para os assalariados dos países centrais hoje (o que não significa que para eles não haja novas e importantes conquistas a fazer), ainda persistem os salários e as condições de trabalho subumanos dos muito mais numerosos trabalhadores dos países periféricos. Aliás, aqui o processo de expulsões de camponeses também está longe de encerrado.

Repetimos: trata-se do segundo tipo de sacrificio, ou seja, de um gesto de generosidade para depois se obter uma bênção do céu. Esta benção se chama progresso e sua manifestação a acumulação de lucros. O sujeito do sacrifício é o capitalista. É ele quem pensa, quem planeja, administra, dá ordens, contrata e despede mão-deobra, compra insumos, etc. O objeto dele - o sacrificado - é, segundo opinião corrente, também o próprio capitalista ${ }^{18}$ e ainda,

${ }^{18}$ Já em meados do século passado o economista inglês Nassau Senior dizia que o lucro provém do trabalho do capitalista e os juros de sua ascese ou abstinência. Ver sobre isso Karl Marx, O capital, Livro I \{1867\}, p. 258, nota 33, Civilizaçđo Brasileira, 1968.

Ainda não faltam recursos para a apologia liberal do empresário oligopolista. Ele é quem sabe o que é que o consumidor precisa, ele se "sacrifica" com os (infelizes) encargos sociais que os governos, pressionados pelos sindicatos trabalhistas, impðem, ele ocorre todos os riscos típicos do investidor (o que não deixa de ensejar sacrificios) e daí merece generosos proventos, etc.

A imposição de rigorosas contençốes salariais aos países pefiféricos pelo Fundo Monetário Internacional nas últimas décadas, tanto nos países onde há inflaçăo galopante como naqueles onde ela é drasticamente contida e onde os salários são de qualquer maneira cronicamente insuficientes para os trabalhadores, para não dizermos subumanos para a grande maiotia deles, é 
concede-se, o trabalhador. No início da expansão marítima da Europa e portanto do mercado mundial, teólogos católicos e protestantes debatiam sobre a possível condição humana do negro e do ameríndio. Hoje já não se nega publicamente a dignidade de todas as pessoas, pois a pregação setecentista a favor da liberdade e igualdade universais, muito embora nunca tivesse pretensões de verdadeira universalidade, deparou-se com novas e imprevistas circunstâncias históricas (que não cabe analisar aqui) que obrigaram a burguesia a fazer concessões formais ao homem comum, mormente nos países centrais.

Ora, se o capitalista é também objeto do sacrificio, deduz-se que tem o direito de participar da graça a alcançar, uma vez que esta seja de fato alcançada. E o trabalhador? Aqui o discurso liberal não consegue explicar o fruto colhido para este. No seu íntimo o megacapitalista de hoje não diverge dos primeiros desbravadores do mercado mundial. O trabalhador - até mesmo que seja branco e fale inglês - é o mais apto a pagar o sacrificio. Não há progresso sem sacrificio, não há glória sem luta. Existem exemplos históricos de religiões que ofertavam sacrificios humanos. Os aztecas sacrificavam prisioneiros de guerra em elaborados rituais. Muitos cananeus ofertavam seus próprios filhos ao deus Moloc. A concorrência, fruto de acumulação de capital, não permite trégua. Ela exige sacrificios. Quando muito, um capitalista pode chorar a imolação de seus pobres trabalhadores. Mas o progresso é exigente. E Moloc é um deus ciumento.

Não sem um toque poético, comentou no século passado para os alunos de uma escola dominical de instrução religiosa um dos maiores empresários da histórica, John D. Rochefeller: "A rosa American Beauty só pode ser cultivada de modo a atingir o máximo esplendor e fragrância que dão grande alegria a quem a apreciar, se os primeiros botões que nascem ao seu redor forem sacrificados". Comentário de John Kenneth Galbraith: "Os mesmos sacrifícios ocorriam no mundo dos negócios e justificavam pro tanto o esplendor de um Rockefeller." Continua John D. Rockefeller: "Essa não é entretanto uma tendência maléfica dos negócios. E 
apenas a execução de uma lei da Natureza e de uma lei de Deus".

A respeito destes comentários divinamente iluminados de Rockefeller, como também de exemplos tirados propriamente de economistas contemporâneos nossos, comentou Júlio de Santa Ana: "Ao exigir o sacrificio a economia política burguesa confirma sua natureza religiosa". 19

$$
-6-
$$

Qual a relação entre nosso conceito de mamonismo e o conceito marxiano de fetichismo?

Não podemos dar um tratamento cabal aqui ao complexo tema do fetichismo. Que baste fazermos aqui aqueles comentários indispensáveis para uma compreensão mínima do conceito para depois compará-lo com o de mamonismo. ${ }^{20}$

Marx observou que as mercadorias são "coisas sociais, com propriedades perceptíveis e imperceptíveis aos sentidos". 21 E seu aspecto imperceptível, o seu caráter social, e não material, que engana as pessoas. "Uma relação social definida, estabelecida entre os homens, assume a forma fantasmagórica de uma relação

${ }^{19}$ Para as citaçóes textuais de Rockefeller e os comentários do próprio Galbraith, ver J. K. Galbraith, A era da incerteza \{1977\}, p. 40-41, Livraria Pioneira Editora, São Paulo, segunda edição revista, 1980.

Entretanto vale frisar que tomamos conhecimento das citações tanto de Rockefeller como de Galbraith através de Júlio de Santa Ana, O amor e as paixôes, p. 76, Editora Santuário, Aparecida, SP, 1989. Dali foi tirado também, claro, o comentário de Santa Ana.

${ }^{20}$ Como nota Norman Geras, o fetichismo é uma categoria muito promissora, vinculado como está a temas como alienação e ideologia. Ver Norman Geras, "Marx and the critique of political economy", em R. Blackburn (org.), Ideology and social science, p. 284-305, Pantheon Books, Nova York, 1972. Geras aqui se refere à ideologia como falsa consciência. Nós porém náo a usamos neste artigo (ou, pelo menos, não necessariamente) neste sentido restrito. $A$ ideologia para nós é, no sentido lato, visão de mundo, a compreensão da sociedade humana: como ela funciona, para que, respeitando que regras, etc. A ideologia define também portanto o que é possivel ou năo, desejável ou não. Ela é tanto lógica como normativa.

No sentido restrito de falsa consciência podemos observar que, para nós, quem pensa e/ou age ideologicamente é somente nosso adversáio ou foi influenciado pelo pensamento dele (quem o internalizou), o que vem a ser a mesma coisa.

${ }^{21}$ Karl Marx, O capital Livro I, p. 81. 
entre coisas. Para encontrar um símile, temos de recorrer à região nebulosa da crença. Aí, os produtos do cérebro humano parecem dotados de vida própria, figuras autônomas que mantêm relações entre si e com os seres humanos. É o que ocorre com os produtos de mão humana, no mundo das mercadorias. Chamo a isto de fetichismo,... \{o que $\}$ é inseparável do mundo das mercadorias". Como os mercantilistas se enganaram ao atribuírem aos metais nobres em si a geração de relações sócio-econômicas entre os homens, e os fisiocratas ao atribuírem a da renda da terra ao solo, os economistas modernos erram ao considerarem o capital como dotado de semelhantes poderes mágicos. ${ }^{23} \mathrm{Ou}$ ainda:

A polêmica monótona e estulta sobre o papel da natureza na criação do valor-de-troca, além de outros fatos, demonstra que uma parte dos economistas está iludida pelo fetichismo dominante no mundo das mercadorias ou pela aparência material que encobre as características sociais do trabalho. Sendo o valor-de-troca uma determinada maneira social de exprimir o trabalho empregado numa coisa, não pode conter mais elementos materiais da natureza do que uma cotação de câmbio. ${ }^{24}$

Mas para o homem de hoje - capitalista ou trabalhador - uma cotação de câmbio, uma ação, uma folha de pagamento ou uma nota promissória, como também o salário, o lucro, o juro ou o aluguel - todos eles são vistos como coisas e não as relaçöes ou símbolos das relações que fazem parte mormente da lógica de um peculiar modo de produção que se chama capitalismo. Ou como diz Simon Mohun, trata-se de uma falsa aparência, e daí falsa consciência, da sociedade hodierna onde ocorre "a degenerescência das relações sociais para relações naturais". 25 Tudo isso faz parte de

22 Ibidem.

${ }^{23}$ Ibidem, Livro I, p. 92.

${ }^{24}$ Ibidem, Livro I, p. 91 .

25 Simon Mohun, "Ideology, knowledge and neoclassical economics", p. 235, em F. Green e P. Nore (orgs.), Issues in political economy. Mohun escreve "the collapse of social relations into 
um grande elenco de crenças que são o credo do capitalismo. Sem dúvida o capitalismo existe e, a seu modo, funciona. Mas ele não é uma coisa, é um complexo conjunto de relações sociais. Enfim, ele é um sistema. O termos escolhido por Marx é muito feliz, pois o que a ideologia burguesa valoriza é um fetiche, um objeto com atributos imaginários e que portanto não existem, mas que, do ponto de vista do observador funcionam como se existissem. Embora seja uma relação social, o capital, ${ }^{26}$ que contrata milhões de trabalhadores e com um estalo de dedos os põe no olho da rua, que trama guerra e golpes de estado e cria modas, gostos e valores, surte efeitos como se fosse coisa.

É possível que o termo mamonismo também derive da religião e da mitologia ${ }^{27}$ o mamonismo pode funcionar (pois, além de ideologia, é também uma práxis), como já vimos, só a partir da reprodução de um excedente econômico. A sociedade neolítica inibiu o mamonismo, mas este (e não só ele) acabou destruindo aquela. Todas as sociedades civilizadas anteriores ao mercado mundial também o inibiram, mas com êxito decrescente.

$O$ fetichismo também reflete uma atitude ideológica. Mas ele só chega a existir a partir de um ambiente onde a produção de mercadorias, e com ela uma dinâmica vida financeira, é crescentemente a regra geral. Marx é muito claro a este respeito. Ele chega até a pincelar sucintamente quatro "formas de produção" isentas de fetichismo: a de um imaginário Robinson Crusoé, que trabalha diligentemente para si numa ilha deserta; a do mundo feudal europeu onde os vários laços de dependência entre os vários estamentos da sociedade tomam conta das próprias relações de produção e onde, portanto, a produção de mercadorias não é a re-

natural ones".

${ }^{26}$ No presente caso capital não se refere aos meios de produção mas sim ao conjunto das relaçôes sociais de produção entre capitalistas e trabalhadores. Por sinal, o próprio Marx quase sempre o emprega neste sentido.

${ }^{27}$ Mamon ou mamona em aramaico significa riqueza ou bens materiais. Parece - mas disso não temos certeza absoluta - que se referia também a uma divindade, ao deus da riqueza. Não obstante esta nossa incerteza, tomamos a liberdade de nos referirmos aqui por vezes a Mamon, com maiúsculo, como suposta divindade para significar uma real e eficaz idolatração (valorização suprema) da posse de bens supérfluos. 
gra; a da patriarcal produção camponesa onde o produto social é consumido pela própria família; finalmente a de uma sociedade socialista de "homens livres" que são remunerados de acordo com seu trabalho dispendido e que consomem o excedente também por este mesmo critério. ${ }^{28}$ Só a segunda e a terceira (se bem que pode existir restrições quanto à terceira) conheceram existência histórica, pois a primeira é puramente imaginária e a última ainda não passa de um possível projeto. ${ }^{29}$

\section{${ }^{28}$ K. Marx. O capital, Livro I, p. 85-88.}

${ }^{29}$ Os modelos político-econômicos do tipo soviético no século XX não eram sociedades organizadas por "trabalhadores livremente associados" como preconizara Marx, e neste sentir' não eram socialistas não obstante o rótulo que tanto seus fundadores como seus inimigos thes atribuíram.

Tratava-se antes de um estatismo produtivista. Os bolchecviques vencedores da história logo na primeira etapa da Revolução (de 1917 a 1928) impuseram suas posturas a ferro e fogo e às custas de uma oposição mais à esquerda no seu próprio partido. Nesta etapa Lênin, Trotsky e outros prestigiaram o crescimento econômico mas marginalizaram a participação popular nele. A insistência de Lênin no taylorismo é um excelente exemplo disso. O crescimento econômico, especialmente na indústria, sob a égide de Stalin, foi quantitativamente estupendo, se bem que qualitativamente dúbio.

Uma sociedade de trabalhadores livremente associados teria conhecido um crescimento mais lento numa longa primeira etapa, mas a nosso ver teria sido muito mais compensadora não obstante os tremendos riscos envolvidos (o que não teria tido pouco a ver com o panorama internacional). Ela teria sido também uma experiência de crescimento econômico sem mamonismo, ou melhor, com um mínimo de mamonismo tolerado. (Pensamos aqui na necessidade de tolerar alguns incentivos materiais para alentar a produtividade, pois as urgentes necessidades do crescimento e certas contradiçôes da sociedade pré-revolucionária teriam que persistir por um certo tempo).

É exatamente isso - um crescimento quase sem mamonismo - o que foi o crescimento estalinista, se bem que com uma face diferente daquela de uma sociedade socialista de trabalhadores livremente associados. Criou-se uma camada dirigente de tecnoburocratas que não tinham o direito legal a proventos sequer de longe comparáveis aos brindados aos capitalistas oligopolistas contemporâneos seus. Não motivados pelo afa do lucro como seus colegas capitalistas nem tampouco por uma delegação de autoridade por mandato popular como no socialismo acima sugerido, muitos dirigentes do estatismo produtivista recorreram ao enriquecimento ilicito e outros atos de corrupção geradores de incompetência. Assim, o que havia de mamonismo entre eles trabalhou contra o sistema embora fosse em última análise cria dele!

Uma compensação ideológica foi uma verdadeira fetichização da produção. Os manuais soviéticos em décadas recentes, visando inclusive fins propagandísticos para um público internacional, se orgulhavam da superação dos Estados Unidos por seu pais na produção de aço e carregaram uma forte tônica de louvor às façanhas de crescentes indices de produção de vários bens. Já na década de 1930 Trotsky pôde escrever no exilio: "Caracterizar o êxito da industrializą̧ão só por seus indices quantitativos é como querer definir a anatomia de um homem por sua esta- 
Em suma, o mamonismo é aquela atitude ou comportamento que exalta a concorrência pelos bens supérfluos, pois estes são tidos como as garantias cabais de prestígio, honra, status, respeito, etc. É uma valorização ideológica que em determinadas circunstâncias históricas se concretiza através da práticas social. $O$ fetichismo, por sua vez, se refere à atribuição fantasmagórica, ao travestimento mental, de relações sociais como se fossem relações entre coisas (mercadorias), como se as mercadorias tivessem em si atributos, os quais porém na realidade existem apenas em razão do sistema em vigor. O mamonismo, enquanto atitude ideológica, é tão antigo quanto a humanidade e nesta capacidade (enquanto apetite) jamais deixará de existir. Para passar da ideologia para a prática coletiva em escala socialmente conseqüente, ele tem como pressuposto mínimo a existência permanente de um excedente. $O$ pressuposto concreto para a existência da atitude fetichista, por outro lado, é a generalização da produção de mercadorias, o que se afinca historicamente só quando da prevalência da mão-de-obra assalariada e da (quase) universal monetarização da economia. Finalmente, o mamonismo reflete uma atitude, uma normatividade ideológica. O fetichismo, por sua vez, é uma interpretação ideológica, é uma tentativa de entender o mundo das mercadorias e a vida social a ele vinculada; e, como não pode deixar de acontecer, ele ainda redunda numa atitude normativa também, a saber, na religião econômica. Esta, aliás, é o ponto de encontro de ambos, mamonismo e fetichismo.

$E$ daí o mamonismo e o fetichismo conhecem um terreno de convergência, a saber, o do sagrado e o do sacrificio. Não é à toa que autores como Hinkelammert ${ }^{36}$ e, até certo ponto, Assmann, inspirados na teoria do fetichismo da mercadoria, escrevem longamente sobre essa dupla temática. Somente num ambiente onde a produção de mercadorias se generaliza, se torna a regra predo-

tura sem indicar a largura do peito". ("La révolution trahie" \{1936\}, em De la révolution, p. 453, Éditions de Minuit, 1963). Era a ideologia do valor-de-uso pelo valor-de-uso, uma espécie de nova religião econômica.

${ }^{30}$ Franz Hinkelammert, As armas ideologicas da morte \{1981\}, Edições Paulinas, Săo Paulo, 1983. 
minante, o que ocorre em escala crescentemente planetária mal faz dois séculos, pode o espírito mamonista exultar a ponto de seduzir imperiosamente ao homem conium como nunca antes. A burguesia, devota máxima de Mamon, gan̉ha respeitabilidade e molda o homem comum a sua imagem e semelhança. Talvez com a única notável exceção do ressurgimento de um fundamentalismo islâmico, as religiões tradicionais, todas de origem preburguesa, perdem terreno para a religião econômica. $O$ discurso oficial relega o desemprego e a pobreza para segundo plano e, se tem que mencioná-los, ensina que são inevitáveis como os terremotos e maremotos. E o fetiche que cativa a mente de bilhões faz crer que o atual funcionamento do mundo é essencialmente o único possível. Inclusive qualquer melhora da saúde da economia poderia ocorrer apenas dentro dos parâmetros em vigor.$$
-7-
$$

Em certo trecho Marx não pộde deixar de elogiar a superioridade moral, o antimamonismo oficial das antigas civilizações, frente à filosofia moderna sobre a produção:

Até agora, a antiga concepção segundo a qual o homem aparece sempre (por muito rígido que seja o caráter de nacional, religiosa ou política que se queira dar à definição) como o objetivo da produção, dir-se-ia que ela é mais elevada que a proporcionada pelo mundo moderno segundo a qual a produção é o objetivo do homem e a riqueza o da produção. ${ }^{31}$

Numa possível sociedade do futuro, onde a produção for planejada e executada através da participação da sociedade como um todo numa economia de abundância, pode-se imaginar que não haverá lugar para o fetichismo, já que não haverá mercadoria e moeda. Mas a propensão para o mamonismo, maior do que na Idade a Pedra (pois um excedente abundante poderá excitar os

${ }^{31}$ Karl Marx, Formaciones económicas precapitalistas, loc, cit. 
apetites de alguns) jamais deixará de existir em grau maior ou menor. Se a humanidade chegar a esta etapa, que hoje não passa de pura utopia, o grande desafio será manter a prevalência do sentimento inequívoco de que, ao invés de a riqueza (a riqueza de uns e portanto a pobreza de outros) ser o objetivo da produção e a produção ser o objetivo do homem, o homem - a humanidade como um todo - seja o objetivo da produção. Noutras palavras, em termos do que hoje é utopia mas amanhã será (esperemos) a realidade social geral, a produção de bens deverá ocorrer para a boa vida de todos, isto é, terá que ser um meio para a boa vida universal e nâo - como no mundo burguês de hoje - um fim em si. Pois o conceito de produção como fim em si - na realidade como a razão da convivência social - tem provocado uma cornucópia humanamente dúbia para uns poucos e a pobreza e até a miséria para muitos. 